\title{
1 Terrestrial invertebrates of dry river beds are not \\ 2 simply subsets of riparian assemblages
}

3 Alisha L. Steward

4 Australian Rivers Institute, Griffith University, 170 Kessels Road, Nathan, Brisbane,

5 Queensland 4111, Australia

6 e-mail: a.steward@griffith.edu.au,phone: +61 73735 6567,fax: +61 737357615

Jonathan C. Marshall

9 Queensland Department of Environment and Resource Management, Ecosciences

10 Precinct, 41 Boggo Road, Dutton Park, Brisbane, Queensland, 4102 Australia 11

12 Fran Sheldon

13 Australian Rivers Institute, Griffith University, 170 Kessels Road, Nathan, Brisbane, 14 Queensland 4111, Australia

CSIRO Mathematics, Informatics and Statistics, Ecosciences Precinct, 41 Boggo

Satish Choy

Queensland Department of Environment and Resource Management, Ecosciences Precinct, 41 Boggo Road, Dutton Park, Brisbane, Queensland, 4102 Australia

Stuart E. Bunn

Australian Rivers Institute, Griffith University, 170 Kessels Road, Nathan, Brisbane, Queensland 4111, Australia

Klement Tockner Biology, Freie Universität Berlin, Mueggelseedamm 310, 12587 Berlin, Germany 
1 Abstract Dry river beds are common worldwide and are rapidly increasing in extent due to

2 the effects of water management and prolonged drought periods due to climate change. While

3 attention has been given to the responses of aquatic invertebrates to drying rivers, little

4 attention has been paid to the terrestrial invertebrates of the dry phase. Dry river beds can be

5 harsh and differ in substrate, topography, microclimate, and inundation frequency when

6 compared to adjacent riparian zones. Given these differences, we predicted that dry river beds

7 provide a unique habitat for terrestrial invertebrates, and that their assemblage composition

8 differs from that in adjacent riparian zones. Dry river beds and riparian zones in Australia and

9 Italy were sampled for terrestrial invertebrates with pitfall traps. Sites covered different

10 substrates, climates, and flow regimes. Dry river beds contained diverse invertebrate

11 assemblages and their composition was consistently different from that of the adjacent riparian

12 zone, irrespective of substrate, climate or hydrology. Although taxa were shared between dry

13 river beds and riparian zones, 66 of 320 taxa occurred only in dry river beds. Differences were

14 due to species turnover, rather than shifts in abundance, indicating that dry river bed

15 assemblages are not simply subsets of riparian assemblages. Some patterns in the invertebrate

16 assemblages were associated with environmental variables, but these associations were

17 statistically weak. We suggest that dry river beds are unique ecosystems in their own right.

18 We discuss potential human stressors and management issues regarding dry river beds and 19 provide recommendations for future research.

20 Key words temporary river, climate change, drought, riparian zone, community

21 composition 


\section{Introduction}

2 Rivers that periodically cease to flow comprise a substantial proportion of the total

3 number, length and discharge of the world's rivers (Tooth 2000). These 'temporary'

4 rivers and streams are found on every continent, and are predicted to increase in their

5 extent and in the duration of their no-flow periods due to the effects of water

6 abstraction for human uses and climate change (Larned et al. 2010). Despite their

7 widespread distribution, temporary rivers and streams remain mostly neglected in

8 water legislation (e.g. EU Water Framework Directive WFD; European Commission

9 2000).

10 Temporary rivers are hydrologically dynamic, with aquatic and terrestrial habitats

11 expanding, contracting, and fragmenting through time (Stanley et al. 1997). The

12 responses of aquatic invertebrates to drying is understood for many river systems (e.g.

13 Boulton and Lake 1992; Stanley et al. 1994; Larned et al. 2007). Little attention,

14 however, has been paid to the responses of terrestrial invertebrates to the drying or

15 wetting of their river bed habitat, although drying wetlands have received some

16 attention (Batzer 2004).

17 The dry beds of temporary rivers and streams can provide habitat for terrestrial

18 invertebrates during times when surface water has contracted or disappeared. They

19 can be sites of high terrestrial invertebrate diversity with ants, beetles, and spiders

20 (Formicidae, Coleoptera, and Arachnida) recorded as the most abundant groups

21 (Wishart 2000; Larned et al. 2007). For example, a dry river bed recorded the highest

22 abundance, species richness and number of unique species from seven different

23 terrestrial habitats sampled in the Namib Desert in southwest Africa (Lalley et al. 24 2006).

25 While riparian zones are well known to link terrestrial and aquatic food-webs 26 along river networks (e.g. Gregory et al. 1991), there is an additional and less well 27 understood link that occurs via the river bed sediments adjacent to flowing rivers.

28 Terrestrial invertebrates such as ground beetles (Carabidae), rove beetles

29 (Staphylinidae), and spiders (Lycosidae), inhabit these sediments and feed

30 predominately on emerging and stranded aquatic invertebrates (Hering and Plachter

31 1997; Batzer 2004; Paetzold et al. 2005), and some grasshoppers feed on algae at the

32 shoreline (Bastow et al. 2002). However, the feeding strategies and food-web 
dynamics of terrestrial invertebrates in dry river beds are unknown. Terrestrial

2 invertebrates of dry river beds may provide an important, high quality food source for

3 aquatic biota when the system re-wets (Wishart 2000).

In contrast to permanent rivers, it is the dry phase of the hydrograph that often dominates temporary rivers, with the wet phase being a disturbance to the dry river bed. Compared to adjacent riparian zones, dry river beds can be harsher ecosystems devoid of vegetation due to flow disturbances in the active channel that mobilize, deposit and scour bed sediments, and they are typically exposed to intense solar radiation and wind. They can also be harsh places for biota due to the high temperatures they experience, with some ground surface temperatures exceeding $60^{\circ} \mathrm{C}$ (Steward, unpublished data). High temperatures affect biota by denaturing nucleic acid and protein molecules, including the degradation of mitochondrial RNA, and by damaging the membranes of intracellular organelles (Tansey and Brock 1972; Hickey and Singer 2004). The most heat-tolerant eukaryotic organisms have an upper temperature limit of approximately $60^{\circ} \mathrm{C}$ (Tansey and Brock 1972), with few exceptions (e.g. polychete worms of hydrothermal vents, Chevaldonné et al. 2000; desert moss, Stark et al. 2009). High temperatures in dry river beds would limit their use by most biota to cooler times of the day (mornings, afternoons, night, cloudy spells, etc.), shaded areas, or cooler spaces within the river bed substrate. Dry river beds also differ from adjacent riparian zones in their substrate composition, topography, microclimate, and inundation frequency. .Riparian zones are cooler than river beds owing to shading by vegetation, and the absorption and reflection of solar radiation by the canopy. Smaller diel temperature ranges have been recorded from riparian zones than from exposed river bed gravel (Tonolla et al. 2010). Riparian zones are subjected to lower erosive forces during floods, due to increased roughness as a consequence of riparian vegetation, and usually contain finer substrate types than the adjacent river bed (Gregory et al. 1991).

Nothing is known about the sources of terrestrial invertebrate colonists of dry river beds as surface water disappears. While it is possible that drying river beds could be colonized by terrestrial invertebrates from the riparian zone and thus share common taxa, given their abovementioned harshness and the differences they exhibit in habitat attributes from adjacent riparian zones, we expect that dry river beds support their own specialized terrestrial invertebrate assemblages. Therefore, we predict that assemblages of terrestrial invertebrates sampled from dry river beds will 
1 differ in their composition from assemblages in adjacent riparian zones. To test this

2 prediction, and to better understand environmental differences between dry river bed and riparian habitats for terrestrial invertebrates, we addressed the following research questions:

\section{Defining the habitats}

ii) If so, what taxa of terrestrial invertebrates contribute to this difference?

iii) How are the dry river bed and adjacent riparian habitats different in environmental attributes that are relevant to the invertebrate assemblages?

iv) Which environmental attributes are associated with patterns in the invertebrate assemblages?

We investigated these questions using samples of terrestrial invertebrates from dry river beds and adjacent riparian zones collected at multiple sites in four Australian river catchments and one Italian river catchment. Catchments with a diversity of different river flow regimes and climate characteristics were chosen for this study to enable us to investigate the geographical and climatic breadth of our prediction that dry river beds harbor unique invertebrate assemblages.

\section{Materials and Methods}

We defined dry river bed habitat as the exposed river bed lacking surface water within a riverine channel. Dry river bed habitat could be located in between patches of surface water, such as isolated pools or waterholes. Dry river bed habitat could also be represented by secondary channels within a braided river network. The dry river beds sampled for this study generally lacked woody vegetation and occasionally contained herbaceous vegetation. We defined riparian habitat as the vegetated banks of rivers and streams but not including the sections of the channel near the low water mark (cf.

7 Naiman and Decamps 1997). Riparian habitat was distinguished from dry river bed

8 habitat by the presence of a distinct woody vegetation type, largely composed of

species adapted to such environments (Gregory et al. 1991). Riparian habitat was also

distinguished from dry river bed habitat by an abrupt change in slope and substrate 31 type. 
River beds that had recently been inundated could potentially be undergoing

2 successional shifts in invertebrate assemblages, from the aquatic phase to the

3 terrestrial phase. We avoided sampling such river beds. This is because we aimed to

4 collect 'true' terrestrial invertebrates, rather than semi-terrestrial or aquatic

5 invertebrates that could temporarily resist desiccation. We determined that the dry

6 river beds sampled had not been inundated for weeks to months prior to sampling,

7 based on reference to nearby stream gauge data, local landowner knowledge, the

8 presence of terrestrial herbaceous plants, the absence of aquatic material such as dead

9 aquatic biota or moist algal mats and the extent of the accumulation of terrestrial

10 organic material such as leaf litter.

\section{Study area}

12 Dry river beds and their adjacent riparian zones were sampled at 22 sites. Eighteen 13 sites were sampled within four river catchments in Australia (Mitchell (six sites),

14 Flinders (six sites), Brisbane (four sites), and Moonie (two sites)), and four sites were 15 sampled within the Tagliamento River catchment in Italy (Table 1, Fig. 1).

16 Catchments were selected to cover different climates, hydrological types and river bed 17 substrate types (Table 1, Fig. 2, 3). Hydrological classification for the Australian 18 rivers was based on Kennard et al. (2010).

19 The Mitchell and Flinders River catchments (Fig. 1, 3) in the Australian wet-dry 20 tropics are monsoonal with peak discharge in the austral summer, resulting in high 21 predictability of the annual wet and dry phases (Fig. 2). Both of these rivers flow into 22 the Gulf of Carpentaria in northern Queensland, Australia. During the dry season, 23 surface water in the Flinders River catchment is largely confined to a series of isolated 24 waterholes, whereas the main channel of the Mitchell River catchment contracts to a 25 sinuous, low flow channel with multiple secondary channels, and the location of the 26 main channel is highly dynamic (Brooks et al. 2009). Large, dry, secondary channels 27 were sampled if surface water was present in the main channel. These secondary 28 channels carry water less often than the primary channel of the Mitchell, but more 29 often than primary channels sampled in some other catchments. The Mitchell River 30 experiences large floods every year (every 'wet' season) that inundate these channels, 31 resulting in a single, large macro-channel (Brooks et al. 2009). Dry river beds were 32 typically wider than $100 \mathrm{~m}$ in the Mitchell River catchment, and wider than $50 \mathrm{~m}$ in 
the Flinders River catchment. Both the Mitchell and Flinders were dominated by fine substrate types (Fig. 3).

The Brisbane and Moonie River catchments are located in south-east Queensland, Australia (Fig. 1). The Brisbane River flows east into Moreton Bay, while the Moonie River is part of the upper Murray-Darling Basin and flows south, joining the sea in South Australia. In both catchments, rainfall is mostly associated with subtropical lows and storms resulting in an unpredictable flow regime (Fig. 2). Rivers and streams in these catchments have dried for months, or even years, at a time. The dry river beds sampled in the Brisbane and Moonie River catchments were less than $10 \mathrm{~m}$ wide. Substrate varied from fine to coarse in the Brisbane River catchment, with cracking clay substrates being typical of the Moonie River catchment (Fig. 3).

The Tagliamento River catchment was selected for sampling in addition to the Australian river catchments, to extend the global relevance of the study. There are no rivers with its type of hydrological regime in Australia (Kennard et al. 2010). The Tagliamento River (Fig. 1, 2, 3) has a flashy flow regime with discharge peaks in spring and autumn, although flow, flood pulses and dry spells may occur at any time of the year (Tockner et al. 2003; Döring et al. 2007). The Tagliamento River is one of the last morphologically intact rivers in the European Alps, containing up to 11 individual channels in the braided middle reaches (Ward et al. 1999). These channels can be dry at times and a section of the entire channel network up to $20 \mathrm{~km}$ long can lose all surface water during low flow conditions (Döring et al. 2007). The width of the active channel containing dry river beds was up to $1 \mathrm{~km}$ wide and substrate was coarse (Fig. 3).

\section{Data collection}

To determine whether the terrestrial invertebrate assemblage composition from dry river bed and riparian habitats was different, we sampled both habitats at each site using pitfall traps. The traps consisted of $250 \mathrm{~mL}$ plastic jars, $77 \mathrm{~mm}$ high and $67 \mathrm{~mm}$ in diameter, filled with 70\% ethanol and glycerol as per Wishart (2000). The ethanol acted as a killing agent and preservative, and a drop of detergent was added to break 
1 efficiency (Williams 1959). Five to six replicate pitfall traps were randomly

2 positioned in each habitat type (dry river bed or riparian) at each site and set for

3 approximately 24 hours. Environmental data were visually estimated from a $1 \mathrm{~m}$

4 diameter area surrounding each pitfall trap (Table 2). Environmental variables were

5 chosen that were expected to influence terrestrial invertebrates. Substrate particle

6 sizes were recorded as a percentage of the area, and defined as follows: silt/clay <

$70.05 \mathrm{~mm}$, sand 0.05 - $2 \mathrm{~mm}$, gravel 2 - $4 \mathrm{~mm}$, pebble 4 - $64 \mathrm{~mm}$, cobble $64-256 \mathrm{~mm}$,

8 bedrock $>256 \mathrm{~mm}$ (Cummins 1962). The following substrate cover variables were

9 recorded as a percentage of the $1 \mathrm{~m}$ diameter area: bare ground, detritus, ground

10 vegetation, sticks, branches, and logs. Canopy cover (\%) above each pitfall trap was

11 also recorded.

12 Terrestrial invertebrates collected in the pitfall traps were identified to family level 13 where possible, then grouped according to morphospecies based on guidelines from 14 the literature (Beattie and Oliver 1994; Oliver and Beattie 1996) and counted.

15 Morphospecies are 'taxa readily separable by morphological differences that are 16 obvious to individuals without extensive taxonomic training' (Oliver and Beattie 17 1996). Estimates of richness of terrestrial invertebrates from pitfall samples have been 18 shown to vary little between morphospecies identified by non-specialists and species 19 identified by specialists (Oliver and Beattie 1996). Species level spatial patterns in 20 invertebrate data can be similar at lower levels of taxonomic resolution, such as genus 21 level (Pik et al. 1999; Cardoso et al. 2004) and family level (Marshall et al. 2006).

All sampling took place between October 2008 and September 2010 during the 'dry' phase. Different rivers dried at different times of the year, and as a result different seasons were sampled in this study. Sites were sampled during the austral spring (October 2009) in the Mitchell and Flinders River catchments, in the austral winter (August 2009) in the Moonie River catchment, in the austral summer (December 2009) in the Brisbane River catchment, and in boreal autumn (September 2010) in the Tagliamento River catchment.

To determine that our sampling effort was sufficient to define habitat richness and abundance at each site, we generated randomised taxon accumulation curves (with 50 randomisations) for dry river bed and riparian replicates within each habitat, site and catchment using the EstimateS software program (Colwell 2006). We found that our sampling design was adequate as habitat-specific estimates of both taxon richness and abundance stabilized with five to six replicate samples (Table 3). 
Statistical analyses ANOSIM results.

All multivariate analyses were conducted in the PRIMER version 6.1.10 software program (Clarke and Gorley 2007). To determine whether the terrestrial invertebrate assemblage composition was different between dry river bed and riparian habitats at each site within each catchment, we used a two-way crossed analysis of similarity (ANOSIM) with 9999 permutations based on a Bray-Curtis association matrix between samples characterised by taxa. In these analyses we tested for differences between habitats (dry river bed and riparian zone), allowing for differences between sites, within each catchment. This allowed us to investigate our prediction that the assemblages would differ between adjacent habitats, and consider the generality of this result across multiple catchments with varying hydrology and climate. The twoway crossed ANOSIM design applied to individual catchments was considered the most suitable (as opposed, for instance, to a nested analysis) because it accounted for two factors, site and catchment, that we a-priori assumed to be major sources of variability not directly related to our research questions, allowing the results to focus on our interest in differences between dry river beds and adjacent riparian zones.

Whilst a standard significance threshold of $p<0.05$ was used to determine if there were differences, pair-wise $R$ values were used to indicate the magnitude of differences between habitats based on the 'rule of thumb' provided by Clarke and Gorley (2006), where $R>0.75$ indicates groups are well separated, $R=0.50-0.75$ indicates overlapping groups that are clearly different, $R=0.25-0.50$ indicates groups with considerable overlap and $R<0.25$ indicates groups are barely separable. We used Non-metric Multi-Dimensional Scaling (NMDS) to graphically display the

Rare taxa were removed prior to analysis because they were considered to be 6 inadequately sampled for us to be confident in our representation of their distributions and thus their inclusion would distort assemblage differences. They were defined as those taxa contributing less than $1 \%$ of the total number of individuals in the catchment-level dataset (i.e. all samples from all sites in a catchment) and contributing less than $5 \%$ of the total number of individuals in their specific sample. 1 The abundance data were $\log _{10}(x+1)$ transformed to down-weight the influence of 2 highly abundant taxa on the assemblage patterns. After down-weighting in this way, 3 association measures between samples better reflect differences in the overall 
assemblage composition (Clarke and Warwick 1994). An additional dataset was created with abundance data transformed to presence-absence (again following removal of rare taxa). Contrasting results of the analyses of the abundance and presence-absence datasets allowed interpretation of the relative contributions of

5 abundance and composition in generating differences between dry river bed and 6 adjacent riparian invertebrate assemblages.

To identify what types of invertebrates contributed to differences between dry river bed and riparian habitats for significant ANOSIM tests, we calculated similarity percentages using SIMPER.

Differences between dry river bed and adjacent riparian habitats in terms of their environmental attributes were assessed using a two-way crossed ANOSIM with 9999 permutations based on a normalised Euclidean distance association matrix between samples characterised by their environmental attributes. This tested for differences between habitat types allowing for differences between sites and was repeated for each catchment. SIMPER was again used to identify which variables contributed most to the significant differences between the habitat types.

To calculate how much of the overall faunal variation in each catchment was associated with environmental variables we used the BIO-ENV routine in PRIMER. The BIO-ENV analyses used Bray-Curtis similarity matrices of the invertebrate data, and a Spearman Rank correlation of environmental variables with normalized Euclidean distance measures.

\section{Results}

\section{Terrestrial invertebrate assemblage composition}

We collected a total of 22,150 invertebrates from 256 pitfall samples from dry river bed and riparian habitats across the five catchments, representing 320 invertebrate morphospecies from 24 orders (Table 4).

There was a significant difference in the composition of terrestrial invertebrate assemblages between dry river bed and adjacent riparian habitats in all 5 catchments (in all cases $p<0.0001$, Table 5, Fig. 4). Applying Clarke and Gorley's (2006) rule of thumb for interpreting ANOSIM results, dry river bed and adjacent riparian assemblages were 'clearly different' when using abundance data in most catchments; however there was 'some overlap' in invertebrate composition in the Mitchell and 
1 Moonie River catchments (Table 5, Fig. 4). Likewise, with presence/absence data,

2 there was a significant difference between dry river bed and adjacent riparian habitats

3 in all 5 catchments, and the magnitudes of the differences were comparable to those

4 from the abundance data results (Table 5).

Total invertebrate abundances were higher in dry river beds than in riparian habitats in the Mitchell and Flinders River catchments, and higher in riparian habitats

8 from riparian than dry river bed habitats. Sixty-six morphospecies (20\% of total) were

9 unique to dry river beds, from the following groups: Coleoptera (35 morphospecies),

10 Formicidae (12), Acarina (3), Diptera (3), Hymenoptera (3), Dermaptera (2),

11 Hemiptera (2), Lepidoptera (2), Orthoptera (2), Collembola (1), and Isoptera (1). Only 12 approximately $50 \%$ of all morphospecies recorded in each Australian catchment were 13 shared between dry river bed and riparian habitats, but this was even lower in the 14 Tagliamento catchment (31\% shared taxa) (Table 4).

Across all catchments, the results from the SIMPER analyses were consistently similar for abundance and presence/absence data, with the top five morphospecies

18 Flinders River catchments, the top five most important morphospecies were

19 Formicidae, Coleoptera and Diptera, with Hemiptera also explaining some of the 20 presence/absence patterns in the Flinders (Table 6). In the Brisbane and Moonie River 21 catchments, the top five most important morphospecies were Formicidae, Collembola and Acarina, with Hemiptera also explaining some of the presence/absence patterns (Table 6). In the Tagliamento River catchment, the top five most important morphospecies were from the Formicidae, Coleoptera, Collembola and Arionoidea groups, with Lycosidae also associated with the presence/absence patterns (Table 6).

\section{Environmental variation}

The environmental characteristics of the dry river beds and riparian zones were significantly different $(p<0.0001)$ in all catchments and the magnitudes were classified as 'clearly different' (Table 5). Large proportions (44-88\%) of these

30 differences were explained by variation in substrate composition and bare ground in 31 all catchments, vegetation cover in all except the Mitchell, and detritus cover in all but 32 the Brisbane (Table 7). 
1 Despite these environmental differences, little of the overall biological patterns

2 were associated with the environmental variation in the BIO-ENV analyses, as

3 indicated by their relatively small $R$ statistics (Table 6). Canopy cover was associated

4 with some of the biological variation in the Mitchell River catchment $(R=0.344, p=$

5 0.001), whereas silt/clay, sand, and detritus was associated with some of the variation

6 in the Flinders River catchment $(R=0.247, p<0.001)$. Silt/clay, sand, cobble and

7 detritus was associated with some of the variation in the Brisbane River catchment $(R$

$8=0.356, p=0.001$ ), whereas sticks, branches and logs were associated with a higher

9 proportion of the faunal variation in the Moonie River catchment $(R=0.602, p=$

10 0.001). In the Tagliamento River catchment, bare ground and vegetation were

11 associated with some of the variation $(R=0.39, p=0.001)$.

\section{Discussion}

\section{Terrestrial invertebrates of dry river beds and riparian habitats}

In every catchment we investigated, the terrestrial invertebrate assemblage composition of dry river beds was significantly different from that in adjacent riparian habitats, as we predicted. These differences were not simply due to the abundances of taxa, but also the presence and absence of taxa. The fact that dry river bed and riparian habitats were significantly different shows that there was sufficient power to detect a difference, even with only 2 sites from the Moonie River catchment.

The dry river bed habitats sampled contained a diverse terrestrial invertebrate assemblage that was dominated by ants (Formicidae) in every catchment but also beetles (Coleoptera) in the Mitchell, Flinders and Tagliamento River catchments and springtails (Collembola) in the Brisbane, Moonie and Tagliamento River catchments, with mites (Acarina), slugs (Arionoidea), flies (Diptera), bugs (Hemiptera) and spiders (Lycosidae) also abundant in some catchments (Table 6, Fig. 5). Similar patterns have been found in dry river beds elsewhere, with high abundances of ants and springtails in New Zealand (Larned et al. 2007), and high abundance of ants, beetles and spiders in South Africa (Wishart 2000) and Namibia (Lalley et al. 2006).

Riparian habitat taxon richness was higher in all catchments, although dry river bed habitats contained more individuals in the Mitchell and Flinders River catchments. Up to half of the taxa were shared between dry river beds and riparian habitats; and 66 out of a total of 320 taxa occurred only in dry river beds. The dry 
1 river bed invertebrate assemblages sampled in this study were not simply subsets of

2 adjacent riparian assemblages differing in taxon abundance. Habitat partitioning

3 amongst taxa appeared to be occurring, with some habitat generalist taxa, some

4 riparian habitat specialists, and some dry river bed habitat specialists. This general

5 pattern has been observed in Lycosid spiders (Moring and Stewart 1994), where

6 overall abundances were higher in exposed cobble streamside habitats than in adjacent

7 grassy riparian zones and some individual species were confined to only one of these

8 habitats or the other, with other species common to both. Dry river beds may contain

9 specialist terrestrial invertebrates with 'inundation-resistant' stages evolved for wet

10 times, much like aquatic invertebrates with desiccation-resistant stages evolved for

11 dry times. This is the case for some terrestrial invertebrates in the flooded forests of

12 the Amazon, which are regularly flooded for up to 6 months of the year. Some

13 invertebrates in these forests have inundation-resistant eggs, and some have

14 physiological adaptations allowing the adults to survive under water (Adis 1986,

15 1992; Adis and Junk 2002).

16 Based on our results, we propose that dry river beds represent habitat for a unique

17 invertebrate assemblage. Our repetition of these results across five different

18 catchments with different zoogeographic histories, hydrology, substrate and climate

19 reinforces the generality of these findings. The differences between dry river bed and

20 riparian invertebrate assemblages can be large, as in the Tagliamento River catchment

21 where the assemblages were clearly different, but the magnitude varied between

22 catchments, with the smallest differences in the Moonie River catchment where the

23 assemblages were different but had considerable overlap.

\section{Environmental differences}

25 The environmental differences between dry river bed and adjacent riparian habitats in

26 each catchment were consistently greater than or equal to the differences in the

27 invertebrate assemblages. Despite this, the overall patterns in invertebrate assemblage

28 composition were not strongly associated with the environmental variability in any

29 catchment. This indicates that our results did not simply reflect a gradient response of

30 the invertebrates to variability in the environment. If such a gradient response existed

31 it would suggest that assemblage composition was tracking environmental variation

32 and that samples with similar environmental attributes would share similar

33 invertebrate assemblages whether they were from the riparian zone or the dry river 
1 bed. The absence of such a gradient response in combination with the consistent

2 faunal difference between habitats further supports our conclusion that dry river beds

3 represent a different ecosystem in their own right.

4 Canopy cover was weakly associated with patterns in the invertebrate assemblages

5 of the Mitchell River catchment. Some of the dry river beds in the Mitchell were

6 extremely wide, up to 500 metres, meaning that most of the dry river bed surfaces

7 were not shaded by riparian vegetation, resulting in a hotter habitat than the adjacent

8 shaded riparian habitat. These river beds resembled hot, sandy deserts by day, but

9 cooled considerably by night. Invertebrate activity in these river beds could well be

10 limited to night time, or else displayed by invertebrates tolerant of extreme

11 temperatures. In the Flinders River catchment, patterns in the invertebrate

12 assemblages were associated with silt/clay, sand, and detritus, but again the statistical

13 association was weak. The dry river bed habitats were predominantly sand, and the

14 riparian habitats were predominately silt/clay, with more detritus on average found in

15 the riparian habitats than in the dry river beds. This was consistent with the Brisbane

16 River catchment, with patterns in the invertebrate assemblages weakly associated with

17 sand and detritus, and also bare ground and cobble, with these substrates mainly found

18 in the dry river beds. Sticks, branches and logs were associated with the invertebrate

19 assemblage patterns in the Moonie River catchment, having the strongest statistical

20 association. Bare ground and vegetation cover were weakly associated with

21 invertebrate patterns in the Tagliamento River catchment. Although over ninety

22 percent of the dry river bed habitats in the Tagliamento were bare, the substrate was

23 coarser than that of the riparian habitats, providing interstitial spaces and complexity

24 that differs from the fine substrates and vegetation cover of the riparian zone. Aspects

25 of the environment that we didn't measure could be more strongly associated with the

26 invertebrate patterns than substrate, canopy cover and ground cover. We measured

27 structural attributes of each habitat, whereas temperature, humidity, and soil moisture

28 may also be important to terrestrial invertebrates and should be considered in future

29 studies.

30 Dry river beds - management and future research

31 Human activities that change the environmental conditions of dry river beds are likely

32 to influence invertebrate assemblage composition. Cattle trampling, weed invasion,

33 siltation, and altered hydrology can impact rivers and streams, the shoreline, and 
1 gravel bars during the wet phase (Balneaves and Hughey 1990; Wood and Armitage

2 1997; Nilsson et al. 2005; Bates et al. 2007; Sadler and Bates 2008), and are likely

3 stressors on dry river beds during the dry phase. Cattle trampling during the dry phase

4 may compact the river bed sediments, siltation may reduce substrate diversity through

5 in-filling, and weed invasion would increase canopy cover or ground vegetation

6 cover, possibly affecting the quality of dry river beds as habitats.

$7 \quad$ Under climate change scenarios, global surface temperatures are predicted to

8 increase by $1-4^{\circ} \mathrm{C}$ during the twenty-first century (Meehl et al. 2007), and these

9 changes may impact the invertebrate assemblages of dry river beds. Temperatures

10 recorded in dry river beds can exceed the thermal tolerances of many organisms;

11 therefore future temperature increases may extend the duration of periods when dry

12 river beds are inhospitable to most life. The combined effects of climate change and

13 water management may increase or decrease the duration of the wet and dry phases in 14 rivers (Jackson et al. 2001; Chiew and McMahon 2002; Lehner et al. 2006). Reduced

15 flood frequency has negatively impacted the aquatic biota of temporary rivers and 16 streams (Jenkins and Boulton 2007), and may have negative effects on habitat and 17 diversity of terrestrial invertebrates in dry river beds. Permanent wetting after the 18 construction of instream barriers such as dams or weirs will be detrimental to the 19 terrestrial invertebrates of dry river beds, eliminating dry river bed habitat altogether. 20 Similarly, increased dry periods may impact dry river bed invertebrates by reducing 21 the opportunities for terrestrial predators and scavengers to consume stranded aquatic 22 material, which may be important for their survival or recruitment.

23 Our study has highlighted the significance of these habitats in supporting unique 24 biota. A key way forward is to test how the terrestrial invertebrates of dry river beds 25 are affected by disturbance. Firstly, biotic responses to alterations of the 26 environmental attributes of dry river beds need to be better described. Secondly, an 27 understanding needs to be developed of how modifications to wetting and drying 28 regimes of temporary rivers effect successional changes in terrestrial invertebrates. If 29 a link between human impacts and terrestrial invertebrate responses is established, 30 then terrestrial invertebrates could be considered as biological indicators of dry river 31 health, in the same way that aquatic invertebrates are often used as indicators of 32 aquatic ecosystem health. 
1 Acknowledgements AS was funded by the Queensland Department of Environment and Resource

2 Management (DERM) and TRaCK (Tropical Rivers and Coastal Knowledge, www.track.gov.au).

3 TRaCK received major funding for its research through the Australian Government's Commonwealth

4 Environment Research Facilities initiative; the Australian Government's Raising National Water

5 Standards Programme; Land and Water Australia and the Queensland Government's Smart State

6 Innovation Fund. Additional support was provided from the European Union through the

7 Mediterranean Intermittent River ManAGEment (MIRAGE) project (ref: FP7 ENV 2007 1,

8 www.mirage-project.eu). We acknowledge DERM for supplying the flow data for the Australian rivers,

9 and IGB for supplying the flow data for the Tagliamento River. Diego Tonolla and Daniel von Schiller

10 assisted with providing Tagliamento River GIS data. Many thanks to the field volunteers: in Australia -

11 Jon and Jo Blessing, Sara Clifford, Ceaira Cottle, Werner Ehrsam, Jimmy Fawcett, Laurisse Frampton,

12 Jess Haxen, Dean Holloway, Barry Kenway, Jaye Lobegeiger, Kate Masci, Morag McKinnon,

13 Courtenay Mills, Annette Ritchie, Rob Rolls, Michael Rooke, Emily Saeck, Bill Senior, Suzanne

14 Sippel, Ilva Sporne, Hamish Sutherland, Kenn Tews, Dominic Valdez, Ben Woodward, Belinda Young

15 and Farah Zavahir; and in Italy - Claudio Cruciat and Brigitte Zoller. Thanks to Rob Rolls and Ben

16 Stewart-Koster for providing statistical advice. We also wish to thank the landowners, particularly Neil

17 and Helen Peddle. We thank the Australian Rivers Institute's Aquatic Ecology Discussion Group

18 ("Dregs") for providing comments on the manuscript. We thank Thibault Datry and the Guest Editor of

19 this issue Dave Arscott. Finally we thank two anonymous referees for providing valuable criticism and

20 excellent suggestions that greatly improved this manuscript. 
Adis J (1986) An "aquatic" millipede from a Central Amazonian inundation forest. Oecologia 68:347-349.

Adis J (1992) How to survive six months in a flooded soil: strategies in Chilopoda and Symphyla from Central Amazonian floodplains. Stud Neotrop Fauna Environ 27:117-129.

Adis J, Junk WJ (2002) Terrestrial invertebrates inhabiting lowland river floodplains of Central Amazonia and Central Europe: a review. Freshw Biol 47:711-731.

Balneaves JM, Hughey K (1990) The need for control of exotic weeds in braided river-beds for conservation of wildlife. In: Proceedings of the 9th Australian Weeds Conference, Adelaide, South Australia, 1990. pp 103-108

Bastow J, Sabo J, Finlay J, Power M (2002) A basal aquatic-terrestrial trophic link in rivers: algal subsidies via shore-dwelling grasshoppers. Oecologia 131:261268.

Bates A, Sadler J, Fowles A (2007) Livestock trampling reduces the conservation value of beetle communities on high quality exposed riverine sediments. Biodivers Conserv 16:1491-1509.

Batzer DP (2004) Movements of upland invertebrates into drying seasonal woodland ponds in northern Minnesota, USA. Wetlands 24:904-907.

Beattie AJ, Oliver I (1994) Taxonomic minimalism. Trends in Ecology \& Evolution 9:488-490.

Boulton AJ, Lake PS (1992) The ecology of two intermittent streams in Victoria, Australia. II. Comparisons of faunal composition between habitats, rivers and years. Freshw Biol 27:99-121.

Brooks AP, Shellberg JG, Knight J, Spencer J (2009) Alluvial gully erosion: an example from the Mitchell fluvial megafan, Queensland, Australia. Earth Surf Proc Land 34:1951-1969.

Cardoso P, Silva I, de Oliveira NG, Serrano ARM (2004) Higher taxa surrogates of spider (Araneae) diversity and their efficiency in conservation. Biol Conserv 117:453-459.

Chevaldonné P, Fisher CR, Childress JJ, Desbruyeres D, Jollivet D, Zal F, Toulmond A (2000) Thermotolerance and the 'Pompeii worms'. Marine Ecology Progress Series 208:293-295.

Chiew FHS, McMahon TA (2002) Modelling the impacts of climate change on Australian streamflow. Hydrol Process 16:1235-1245.

Clarke K, Gorley R (2006) PRIMER v6: User Manual/Tutorial. PRIMER-E, Plymouth 
1 Clarke K, Gorley R (2007) PRIMER-6. 6.1.10 edn. PRIMER-E Ltd, Plymouth

2 Clarke KR, Warwick RM (1994) Change in marine communities: An approach to statistical analysis and interpretation. Plymouth Marine Laboratory, Plymouth.

Colwell RK (2006) EstimateS: statistical estimation of species richness and shared species from samples (software and user's guide). 8 edn., http://purl.oclc.org/estimates

Cummins KW (1962) An evaluation of some techniques for the collection and analysis of benthic samples with special emphasis on lotic waters. Am Midl Nat 67:477-504.

Döring M, Uehlinger U, Rotach A, Schläpfer DR, Tockner K (2007) Ecosystem expansion and contraction dynamics along a large Alpine alluvial corridor (Tagliamento River, Northeast Italy). Earth Surf Proc Land 32:1693-1704.

European Commission (2000) Directive 2000/60/EC of the European Parliament and of the Council of 23 October 2000 establishing a framework for Community action in the field of water policy. Official Journal of the European Communities 327:1-7.

Gregory SV, Swanson FJ, McKee WA, Cummins KW (1991) An ecosystem perspective of riparian zones. Bioscience 41:540-551.

Hering D, Plachter H (1997) Riparian ground beetles (Coleoptera, Carabidae) preying on aquatic invertebrates: a feeding strategy in alpine floodplains. Oecologia 111:261-270.

Hickey DA, Singer GAC (2004) Genomic and proteomic adaptations to growth at high temperature. Genome Biology 5:117.

Jackson RB, Carpenter SR, Dahm CN, McKnight DM, Naiman RJ, Postel SL, Running SW (2001) Water in a Changing World. Ecol Appl 11:1027-1045.

Jenkins KM, Boulton AJ (2007) Detecting impacts and setting restoration targets in arid-zone rivers: aquatic micro-invertebrate responses to reduced floodplain inundation. Journal of Applied Ecology 44:823-832.

Kennard MJ, Pusey BJ, Olden JD, Mackay SJ, Stein JL, Marsh N (2010) Classification of natural flow regimes in Australia to support environmental flow management. Freshw Biol 55:171-193.

Lalley JS, Viles HA, Henschel JR, Lalley V (2006) Lichen-dominated soil crusts as arthropod habitat in warm deserts. J Arid Environ 67:579-593.

Larned S, Datry T, Robinson C (2007) Invertebrate and microbial responses to inundation in an ephemeral river reach in New Zealand: effects of preceding dry periods. Aquat Sci 69:554-567.

Larned ST, Datry T, Arscott DB, Tockner K (2010) Emerging concepts in temporaryriver ecology. Freshw Biol 55:717-738. 
Lehner B, Doell P, Alcamo J, Henrichs T, Kaspar F (2006) Estimating the Impact of Global Change on Flood and Drought Risks in Europe: A Continental, Integrated Analysis. Clim Change 75:273-299.

Marshall JC, Steward AL, Harch BD (2006) Taxonomic resolution and quantification of freshwater macroinvertebrate samples from an Australian dryland river: the benefits and costs of using species abundance data. Hydrobiologia 572:171194.

Meehl GA, T.F. Stocker, W.D. Collins, P. Friedlingstein, A.T. Gaye, J.M. Gregory, A. Kitoh, R. Knutti, J.M. Murphy, A. Noda, S.C.B. Raper, I.G. Watterson, A.J. Weaver, Z.-C. Zhao (2007) Global Climate Projections. In: Solomon S, D. Qin, M. Manning et al. (eds) Climate Change 2007: The Physical Science Basis. Contribution of Working Group I to the Fourth Assessment Report of the Intergovernmental Panel on Climate Change (IPCC). Cambridge University Press, Cambridge, United Kingdom and New York, NY, USA, pp 747-845

Moring JB, Stewart KW (1994) Habitat partitioning by the wolf spider (Araneae, Lycosidae) guild in streamside and riparian vegetation zones of the Conejos River, Colorado. Journal of Arachnology 22:205-217.

Naiman RJ, Decamps H (1997) The ecology of interfaces: riparian zones. Annu Rev Ecol Syst 28:621-658.

Nilsson C, Reidy CA, Dynesius M, Revenga C (2005) Fragmentation and flow regulation of the world's large river systems. Science 308:405.

Oliver I, Beattie AJ (1996) Invertebrate morphospecies as surrogates for species: a case study. Conserv Biol 10:99-109.

Paetzold A, Schubert CJ, Tockner K (2005) Aquatic terrestrial linkages along a braided-river: Riparian arthropods feeding on aquatic insects. Ecosystems 8:748-759.

Pik AJ, Oliver I, Beattie AJ (1999) Taxonomic sufficiency in ecological studies of terrestrial invertebrates. Aust J Ecol 24:555-562.

Queensland Department of Environment and Resource Management (2010) http://www.derm.qld.gov.au/water/monitoring/index.html Accessed 11 October 2010

Sadler JP, Bates AJ (2008) The ecohydrology of invertebrates associated with exposed riverine sediments. In: Wood PJ, Hannah DM, Sadler JP (eds) Hydroecology and Ecohydrology. John Wiley \& Sons Ltd, pp 37-56

Stanley EH, Buschman DL, Boulton AJ, Grimm NB, Fisher SG (1994) Invertebrate resistance and resilience to intermittency in a desert stream. Am Midl Nat 131:288-300.

Stanley EH, Fisher SG, Grimm NB (1997) Ecosystem expansion and contraction in streams. Bioscience 47:427-435. 
Stark LR, McLetchie DN, Roberts SP (2009) Gender differences and a new adult eukaryotic record for upper thermal tolerance in the desert moss Syntrichia caninervis. Journal of Thermal Biology 34:131-137.

Tansey MR, Brock TD (1972) The upper temperature limit for eukaryotic organisms. Proceedings of the National Academy of Sciences of the United States of America 69:2426.

Tockner K, Ward JV, Arscott DB, Edwards PJ, Kollmann J, Gurnell AM, Petts GE, Maiolini B (2003) The Tagliamento River: A model ecosystem of European

Tonolla D, Acuña V, Uehlinger U, Frank T, Tockner K (2010) Thermal heterogeneity in river floodplains. Ecosystems 13:727-740.

Wood PJ, Armitage PD (1997) Biological effects of fine sediment in the lotic

Tooth S (2000) Process, form and change in dryland rivers: a review of recent research. Earth-Science Reviews 51:67-107.

Ward JV, Tockner K, Edwards PJ, Kollmann J, Bretschko G, Gurnell AM, Petts GE, Rossaro B (1999) A reference river system for the Alps: The 'Fiume Tagliamento'. Regulated Rivers-Research \& Management 15:63-75.

Williams G (1959) The seasonal and diurnal activity of the fauna sampled by pitfall traps in different habitats. J Anim Ecol 28:1-13.

Wishart MJ (2000) The terrestrial invertebrate fauna of a temporary stream in southern Africa. Afr Zool 35:193-200. environment. Environ Manage 21:203-217. 


\section{Tables}

Table 1 Catchment and site characteristics. References are provided in parentheses. Site codes are those used in Fig. 5.

\begin{tabular}{|c|c|c|c|c|c|c|c|c|c|c|}
\hline Country & Catchment & $\begin{array}{l}\text { Catchment } \\
\operatorname{area}\left(\mathbf{k m}^{2}\right)\end{array}$ & $\begin{array}{c}\text { Discharge: } \\
\text { mean annual flow / } \\
\text { max. annual flow } \\
\text { (ML) }\end{array}$ & Climate & $\begin{array}{l}\text { Hydrology of } \\
\text { sampled sites }\end{array}$ & $\begin{array}{c}\text { Dominant river } \\
\text { bed substrate of } \\
\text { sampled sites }\end{array}$ & Site & Latitude & Longitude & $\begin{array}{l}\text { Site } \\
\text { code }\end{array}$ \\
\hline \multirow[t]{7}{*}{ Australia } & Mitchell & $\begin{array}{c}45,872 \\
(\mathrm{a}, \mathrm{b})\end{array}$ & $\begin{array}{l}8,153,011 / \\
31,104,532\end{array}$ & $\begin{array}{l}\text { Wet-dry } \\
\text { tropical }\end{array}$ & $\begin{array}{l}\text { Predictable } \\
\text { flow }\end{array}$ & $\begin{array}{l}\text { Sand and gravel, } \\
\text { gravel and pebble }\end{array}$ & & & & \\
\hline & & & $(a, b)$ & & & & Walsh River at Ferguson Crossing & -16.9905 & 144.2979 & M1 \\
\hline & & & & & & & Mitchell River at Lynd Junction & -16.4642 & 143.3104 & M2 \\
\hline & & & & & & & Mitchell River at Hughs Crossing & -16.3434 & 143.0632 & M3 \\
\hline & & & & & & & Lynd River at Dickson Hole & -17.4944 & 143.9617 & M4 \\
\hline & & & & & & & Rosser Creek at Drumduff Road & -16.2492 & 143.0248 & M5 \\
\hline & & & & & & & Mitchell River at Koolatah & -15.9663 & 142.4203 & M6 \\
\hline \multirow[t]{6}{*}{ Australia } & Flinders & $\begin{array}{c}106,263 \\
(\mathrm{a}, \mathrm{c})\end{array}$ & $\begin{array}{c}3,093,672 / \\
18,001,419 \\
(a, c)\end{array}$ & $\begin{array}{l}\text { Wet-dry } \\
\text { tropical }\end{array}$ & $\begin{array}{l}\text { Predictable } \\
\text { flow }\end{array}$ & $\begin{array}{l}\text { Silt/clay and sand, } \\
\text { sand and gravel, } \\
\text { gravel and cobble }\end{array}$ & Flinders River at Walkers Bend & -18.1624 & 140.8570 & $\mathrm{~F} 1$ \\
\hline & & & & & & & Cloncurry River at Cowan Downs & -18.9986 & 140.6021 & $\mathrm{~F} 2$ \\
\hline & & & & & & & Cloncurry River at Ten Mile Waterhole & -19.3312 & 140.8485 & F3 \\
\hline & & & & & & & Flinders River at Rocky Waterhole & -20.2430 & 141.8476 & $\mathrm{~F} 4$ \\
\hline & & & & & & & Cloncurry River at Stanley Waterhole & -19.5537 & 141.0118 & F5 \\
\hline & & & & & & & Cloncurry River at Sedan Dip & -20.0383 & 141.1084 & F6 \\
\hline \multirow[t]{5}{*}{ Australia } & Brisbane & $\begin{array}{c}10,172 \\
(\mathrm{a}, \mathrm{d})\end{array}$ & $\begin{array}{l}854,130 / \\
4,130,506\end{array}$ & Subtropical & $\begin{array}{c}\text { Unpredictable } \\
\text { flow }\end{array}$ & $\begin{array}{l}\text { Gravel and cobble, } \\
\text { silt/clay and sand }\end{array}$ & & & & \\
\hline & & & (a, d) & & & & Reynolds Creek at Munchow Road & -28.1042 & 152.5178 & $\mathrm{~B} 1$ \\
\hline & & & & & & & Wild Cattle Creek at Wild Cattle Creek Road & -28.1040 & 152.5160 & $\mathrm{~B} 2$ \\
\hline & & & & & & & Oaky Creek at Esk-Crows Nest Road & -27.1611 & 152.2818 & B3 \\
\hline & & & & & & & Purga Creek at Loamside & -27.6831 & 152.7291 & B4 \\
\hline \multirow[t]{2}{*}{ Australia } & Moonie & 12,025 & $124,409 /$ & Subtropical & Unpredictable & Silt/clay & & & & \\
\hline & & $(\mathrm{a}, \mathrm{e})$ & 554,506 & & flow & & Stephens Creek at Bendee Road & -27.8997 & $\begin{array}{l}149.8316 \\
21\end{array}$ & Mo1 \\
\hline
\end{tabular}


(Queensland Department of Environment and Resource Management 2010)

${ }^{\mathrm{b}}$ Mitchell River at Koolatah, Gauging Station 919009A, 1/10/1971 - 1/10/2004

${ }^{c}$ Flinders River at Walkers Bend, Gauging Station 915003A, 1/10/1968 - 1/10/2006

${ }^{\mathrm{d}}$ Brisbane River at Savages Crossing, Gauging Station 143001C, 1/10/1908 - 1/10/2007

${ }^{\mathrm{e}}$ Moonie River at Nindigully, Gauging Station 417201B, 1/10/1953 - 1/10/2006

f Taliamento River at Pioverno, 1929-1939 (Tockner et al. 2003)

Stephens Creek near Westmar

$-27.9004$

149.7185

$\begin{array}{cccccc}\text { Italy Tagliamento } & 1,900 & 3,830,000 / & \text { Alpine } & \text { Unpredictable } & \text { Gravel and cobble } \\ & \text { (f) } & 5,180,000 & \text { flow } & \\ & & \text { (f) } & & \end{array}$

Tagliamento River at Villuzza

46.1734

12.9579

46.0549

12.9166

46.2035

12.9744 


\begin{tabular}{|c|c|c|c|c|c|c|c|c|c|c|}
\hline \multirow{2}{*}{$\begin{array}{l}\text { Environmental } \\
\text { variables }\end{array}$} & \multicolumn{2}{|l|}{ Mitchell } & \multicolumn{2}{|l|}{ Flinders } & \multicolumn{2}{|l|}{ Brisbane } & \multicolumn{2}{|l|}{ Moonie } & \multicolumn{2}{|l|}{ Tagliamento } \\
\hline & B & $\mathrm{R}$ & B & $\mathrm{R}$ & B & $\mathrm{R}$ & B & $\mathrm{R}$ & B & $\mathrm{R}$ \\
\hline \% Canopy cover & $12(0-90)$ & $36(0-95)$ & $6(0-70)$ & $24(0-80)$ & $28(0-80)$ & $51(0-90)$ & NA & NA & 0 & $34(0-90)$ \\
\hline$\%$ Silt/clay & $15(0-100)$ & $90(10-100)$ & $13(0-100)$ & $81(5-100)$ & $14(0-60)$ & $79(10-100)$ & $100(100-100)$ & $100(100-100)$ & $11(0-75)$ & $48(0-100)$ \\
\hline$\%$ Sand & $45(0-100)$ & $5(0-80)$ & $46(0-100)$ & $13(0-80)$ & $20(0-80)$ & $6(0-90)$ & 0 & 0 & $18(0-90)$ & $43(0-100)$ \\
\hline$\%$ Gravel & $22(0-60)$ & $2(0-40)$ & $17(0-35)$ & $1(0-20)$ & $9(0-20)$ & $3(0-10)$ & 0 & 0 & $10(5-30)$ & $3(0-25)$ \\
\hline$\%$ Pebble & $13(0-75)$ & $1(0-35)$ & $13(0-75)$ & $0.7(0-5)$ & $22(0-50)$ & $3(0-15)$ & 0 & 0 & $40(5-75)$ & $6(0-85)$ \\
\hline$\%$ Cobble & $2(0-25)$ & $0.3(0-10)$ & $11(0-60)$ & $0.7(0-10)$ & $34(0-70)$ & $9(0-50)$ & 0 & 0 & $21(0-70)$ & $0.7(0-5)$ \\
\hline$\%$ Boulder & $0.4(0-10)$ & 0 & $0.7(0-15)$ & 0 & $2(0-15)$ & $0.3(0-5)$ & 0 & 0 & 0 & 0 \\
\hline$\%$ Bedrock & $2(0-30)$ & $0.7(0-25)$ & $0.3(0-10)$ & $4(0-70)$ & $0.3(0-5)$ & 0 & 0 & 0 & 0 & 0 \\
\hline$\%$ Bare & $79(15-100)$ & $31(1-95)$ & $87(45-100)$ & $34(5-90)$ & $51(20-90)$ & $12(0-55)$ & $70(50-90)$ & $12(0-55)$ & $92(75-100)$ & $32(0-80)$ \\
\hline$\%$ Ground vegetation & $0.2(0-5)$ & $6(0-35)$ & $1.2(0-20)$ & $28(0-75)$ & $8(0-35)$ & $49(15-80)$ & $5(0-15)$ & $18(0-60)$ & $5(0-15)$ & $39(10-75)$ \\
\hline$\%$ Detritus & $17(0-65)$ & $54(5-85)$ & $7(0-45)$ & $32(5-65)$ & $31(5-60)$ & $32(15-50)$ & $19(10-45)$ & $46(20-75)$ & $2(0-5)$ & $24(5-70)$ \\
\hline$\%$ Sticks & $2(0-5)$ & $6(0-15)$ & $3(0-20)$ & $5(0-20)$ & $7(0-15)$ & $6(0-15)$ & $4(0-10)$ & $16(5-30)$ & $0.4(0-5)$ & $5(0-30)$ \\
\hline$\%$ Branches & $0.6(0-10)$ & $1(0-10)$ & $0.9(0-5)$ & $1(0-10)$ & $3(0-20)$ & $2(0-20)$ & $1(0-5)$ & $4(0-20)$ & 0 & $0.2(0-5)$ \\
\hline$\% \operatorname{Logs}$ & $0.7(0-15)$ & $0.6(0-20)$ & $0.4(0-15)$ & $0.4(0-5)$ & $0.5(0-10)$ & 0 & $0.8(0-5)$ & $3(0-30)$ & $0.2(0-5)$ & 0 \\
\hline Channel width & $>100 \mathrm{~m}$ & & $>50 \mathrm{~m}$ & & $<10 \mathrm{~m}$ & & $<10 \mathrm{~m}$ & & $>50 \mathrm{~m}$ & \\
\hline Closest surface water & $>50 \mathrm{~m}$ & & $>50 \mathrm{~m}$ & & $>10 \mathrm{~m}$ & & $>1000 \mathrm{~m}$ & & $>50 \mathrm{~m}$ & \\
\hline $\begin{array}{l}\text { Estimated time since } \\
\text { river bed was last } \\
\text { inundated }\end{array}$ & $>3$ months & & $>3$ months & & $>1$ month & & $>3$ months & & $>1$ month & \\
\hline
\end{tabular}


1 Table 3 Percentage (\%) of taxa from dry river bed (B) and riparian (R) habitats from each catchment

2 collected in the corresponding number of samples (1-6) as calculated from species accumulation

3 curves.

\begin{tabular}{|c|c|c|c|c|c|c|c|c|c|c|}
\hline \multirow[b]{2}{*}{ Number of samples } & \multicolumn{2}{|c|}{ Mitchell } & \multicolumn{2}{|c|}{ Flinders } & \multicolumn{2}{|c|}{ Brisbane } & \multicolumn{2}{|c|}{ Moonie } & \multicolumn{2}{|c|}{ Tagliamento } \\
\hline & $\mathrm{B}$ & $\mathrm{R}$ & $\mathrm{B}$ & $\mathrm{R}$ & $\mathrm{B}$ & $\mathrm{R}$ & $\mathrm{B}$ & $\mathrm{R}$ & $\mathrm{B}$ & $\mathrm{R}$ \\
\hline 1 & 21 & 20 & 28 & 24 & 34 & 37 & 39 & 46 & 22 & 22 \\
\hline 2 & 34 & 33 & 44 & 38 & 51 & 54 & 53 & 67 & 36 & 40 \\
\hline 3 & 43 & 43 & 55 & 48 & 63 & 65 & 62 & 79 & 47 & 54 \\
\hline 4 & 51 & 51 & 62 & 55 & 70 & 72 & 70 & 87 & 55 & 67 \\
\hline 5 & 57 & 57 & 68 & 61 & 75 & 77 & 76 & 92 & 62 & 78 \\
\hline 6 & 63 & 63 & 73 & 65 & 80 & 81 & 81 & 95 & 68 & 87 \\
\hline $\begin{array}{l}\text { Total number of } \\
\text { samples collected }\end{array}$ & 36 & 36 & 36 & 36 & 20 & 20 & 12 & 12 & 24 & 24 \\
\hline
\end{tabular}

4

5 Table 4 Summary of the terrestrial invertebrate morphospecies ('taxa') collected from dry river bed (B)

6 and riparian habitats $(\mathrm{R})$ in each catchment.

\begin{tabular}{|c|c|c|c|c|c|c|c|c|c|c|c|c|}
\hline \multirow[b]{3}{*}{ Catchment } & \multirow[b]{3}{*}{ Taxa } & \multicolumn{6}{|c|}{ Unique taxa } & \multicolumn{5}{|c|}{ Abundance } \\
\hline & & \multicolumn{2}{|c|}{ Shared taxa } & \multicolumn{2}{|l|}{ B } & \multicolumn{2}{|l|}{$\mathrm{R}$} & & \multicolumn{2}{|l|}{ B } & \multicolumn{2}{|l|}{$\mathrm{R}$} \\
\hline & & Total & $\%$ & Total & $\%$ & Total & $\%$ & Total & Total & $\%$ & Total & $\%$ \\
\hline Mitchell & 75 & 36 & 48 & 12 & 16 & 27 & 36 & 4,639 & 3,303 & 71 & 1,336 & 29 \\
\hline Flinders & 95 & 48 & 51 & 18 & 19 & 29 & 31 & 8,717 & 6,732 & 77 & 1,985 & 23 \\
\hline Brisbane & 119 & 60 & 50 & 27 & 23 & 32 & 27 & 8,079 & 1,695 & 21 & 6,384 & 79 \\
\hline Moonie & 63 & 32 & 51 & 7 & 11 & 24 & 38 & 284 & 119 & 42 & 165 & 58 \\
\hline Tagliamento & 109 & 34 & 31 & 14 & 13 & 61 & 56 & 431 & 176 & 41 & 255 & 59 \\
\hline
\end{tabular}

8 Table 5 Global $R$ values from two-way crossed Analysis of Similarity (ANOSIM) comparing dry river

9 bed and riparian habitats, allowing for differences between sites. All results have $p$ values of $<0.0001$.

\begin{tabular}{lllll}
\hline Catchment & Samples & Abundance data & Presence/absence data & Environmental data \\
\hline Mitchell & 72 & 0.44 & 0.46 & 0.56 \\
Flinders & 72 & 0.59 & 0.47 & 0.69 \\
Brisbane & 40 & 0.63 & 0.41 & 0.64 \\
Moonie & 24 & 0.40 & 0.42 & 0.66 \\
Tagliamento & 48 & 0.73 & 0.70 & 0.72 \\
\hline
\end{tabular}




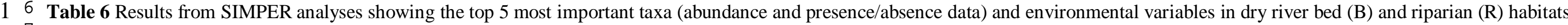
28 in each catchment.

\begin{tabular}{|c|c|c|c|c|c|c|c|c|c|c|c|c|c|c|c|}
\hline $9^{-}$ & \multicolumn{5}{|c|}{ Invertebrate abundance data } & \multicolumn{5}{|c|}{ Invertebrate presence/absence data } & \multicolumn{5}{|c|}{ Environmental data } \\
\hline $\begin{array}{l}10 \\
11 \\
12 \\
13 \\
\end{array}$ & Taxa & $\begin{array}{l}\text { B } \\
\text { average } \\
\text { abundance }\end{array}$ & $\begin{array}{l}\mathrm{R} \\
\text { average } \\
\text { abundance }\end{array}$ & $\begin{array}{l}\text { Contribution } \\
\%\end{array}$ & $\begin{array}{l}\text { Cumulative } \\
\%\end{array}$ & Taxa & $\begin{array}{l}\text { B } \\
\text { average } \\
\text { abundance }\end{array}$ & $\begin{array}{l}\mathrm{R} \\
\text { average } \\
\text { abundance }\end{array}$ & $\begin{array}{l}\text { Contribution } \\
\%\end{array}$ & $\begin{array}{l}\text { Cumulative } \\
\%\end{array}$ & Variables & $\begin{array}{l}\mathrm{B} \\
\text { average } \\
\text { value }\end{array}$ & $\begin{array}{l}\mathrm{R} \\
\text { average } \\
\text { value }\end{array}$ & $\begin{array}{l}\text { Contribution } \\
\%\end{array}$ & $\begin{array}{l}\text { Cumulative } \\
\%\end{array}$ \\
\hline 14 Mitchell & Formicidae 7 & 2.61 & 1.96 & 10.2 & 10.2 & Diptera2 & 0.19 & 0.5 & 5.63 & 5.63 & Silt/Clay & -0.81 & 0.81 & 10.44 & 10.44 \\
\hline 15 & Formicidae8 & 0.78 & 0.7 & 8.04 & 18.2 & Formicidae8 & 0.39 & 0.39 & 5.45 & 11.1 & Sand & 0.62 & -0.62 & 8.75 & 19.19 \\
\hline 16 & Formicidae 9 & 0.6 & 0.71 & 6.65 & 24.9 & Formicidae 9 & 0.31 & 0.36 & 4.61 & 15.7 & Bare & 0.71 & -0.71 & 8.66 & 27.85 \\
\hline 17 & Coleoptera 1 & 0.93 & 0.04 & 4.97 & 29.9 & Coleoptera1 & 0.42 & 0.06 & 3.98 & 19.7 & Detritus & -0.66 & 0.66 & 8.38 & 36.23 \\
\hline 18 & Coleoptera2 & 1.1 & 0.13 & 4.84 & 34.7 & Diptera1 & 0.33 & 0.14 & 3.95 & 23.6 & Gravel & 0.56 & -0.56 & 7.81 & 44.04 \\
\hline 19 Flinders & Coleoptera1 & 2.08 & 0.06 & 10.6 & 10.6 & Coleoptera1 & 0.75 & 0.06 & 6.39 & 6.39 & Silt/Clay & -0.77 & 0.77 & 9.75 & 9.75 \\
\hline 21 & Diptera3 & 1.45 & 0.32 & 7.27 & 17.9 & Coleoptera2 & 0.56 & 0.03 & 5 & 11.4 & Bare & 0.81 & -0.81 & 9.72 & 19.47 \\
\hline 22 & Formicidae8 & 1.07 & 0.76 & 5.82 & 23.7 & Hemiptera2 & 0.25 & 0.56 & 4.94 & 16.3 & Gravel & 0.67 & -0.67 & 8.45 & 27.92 \\
\hline 23 & Diptera2 & 1.23 & 0.86 & 4.7 & 28.4 & Diptera1 & 0.36 & 0.44 & 4.3 & 20.6 & Ground vegetation & -0.63 & 0.63 & 8.3 & 36.22 \\
\hline 24 & Formicidae 2 & 0.82 & 0.15 & 4.49 & 32.9 & Formicidae8 & 0.47 & 0.36 & 3.91 & 24.5 & Detritus & -0.66 & 0.66 & 8.25 & 44.48 \\
\hline$2 5 \longdiv { \text { Brisbane } }$ & Formicidae 1 & 1.65 & 3.4 & 9.7 & 9.7 & Acarina2 & 0.4 & 0.75 & 5.9 & 5.9 & Silt/Clay & -0.69 & 0.92 & 11.3 & 11.3 \\
\hline 26 & Formicidae2 & 1.43 & 2.46 & 6.94 & 16.6 & Orthoptera1 & 0.5 & 0.2 & 5.88 & 11.8 & Ground vegetation & -0.683 & 0.91 & 9.94 & 21.24 \\
\hline 27 & Hemiptera1 & 0.07 & 1.22 & 5.66 & 22.3 & Hemiptera1 & 0.1 & 0.65 & 5.7 & 17.5 & Pebble & 0.45 & -0.60 & 9.72 & 30.96 \\
\hline 29 & Collembola1 & 2.74 & 2.24 & 5.36 & 27.7 & Diptera1 & 0.5 & 0.45 & 4.97 & 22.4 & Canopy cover & -0.29 & 0.38 & 8.66 & 39.62 \\
\hline 30 & Acarina2 & 0.41 & 1.05 & 5.07 & 32.7 & Acarina3 & 0.35 & 0.4 & 4.7 & 27.1 & Bare & 0.61 & -0.81 & 8.07 & 47.69 \\
\hline 31 Moonie & Formicidae 1 & 3.71 & 2.94 & 9.08 & 9.08 & Collembola2 & 0.83 & 0.25 & 8.56 & 8.56 & Bare & 0.88 & -0.88 & 21.5 & 21.5 \\
\hline 32 & Collembola2 & 1.11 & 0.37 & 8.73 & 17.8 & Formicidae 4 & 0 & 0.75 & 8.39 & 17 & Detritus & -0.68 & 0.68 & 19.18 & 40.68 \\
\hline 33 & Formicidae 4 & 0 & 1.03 & 7.95 & 25.8 & Formicidae 6 & 0.17 & 0.58 & 6.7 & 23.7 & Sticks & -0.72 & 0.72 & 18.15 & 58.83 \\
\hline 34 & Formicidae5 & 0.37 & 0.61 & 6.3 & 32.1 & Acarina1 & 0.25 & 0.58 & 6.21 & 29.9 & Ground vegetation & -0.41 & 0.41 & 18.03 & 76.86 \\
\hline 35 & Acarina1 & 0.21 & 0.8 & 5.92 & 38 & Hemiptera2 & 0.42 & 0.42 & 6.1 & 36 & Logs & -0.20 & 0.20 & 11.69 & 88.54 \\
\hline 37 Tag. & FormicidaeT10 & 0.6 & 1.06 & 8.13 & 8.13 & ColeopteraT3 & 0.67 & 0.04 & 4.78 & 4.78 & Bare & -0.84 & 0.84 & 10.91 & 10.91 \\
\hline 38 & CollembolaT3 & 0.72 & 0.78 & 6 & 14.1 & FormicidaeT10 & 0.33 & 0.54 & 4.42 & 9.2 & Ground vegetation & 0.80 & -0.80 & 10.07 & 20.98 \\
\hline 39 & ColeopteraT3 & 0.86 & 0.05 & 5.86 & 20 & CollembolaT3 & 0.33 & 0.58 & 4.08 & 13.3 & Pebble & -0.65 & 0.65 & 8.92 & 29.9 \\
\hline 40 & ArionoideaT1 & 0 & 0.83 & 5.53 & 25.5 & LycosidaeT1 & 0.5 & 0.08 & 3.85 & 17.1 & Cobble & -0.65 & 0.65 & 8.79 & 38.69 \\
\hline 41 & CollembolaT4 & 0.4 & 0.71 & 5.29 & 30.8 & ArionoideaT1 & 0 & 0.5 & 3.74 & 20.9 & Detritus & 0.62 & -0.62 & 8.79 & 47.48 \\
\hline
\end{tabular}

$3^{42}$

43

44

45

46

47 
1 Table 7 Summary of BIONENV analysis results of environmental variables that are associated with the

2 patterns in the dry river bed and riparian invertebrate assemblage composition.

\begin{tabular}{lrrrl}
\hline Catchment & $R$ statistic & $R^{2}$ & $p$ & Environmental variables \\
\hline Mitchell & 0.344 & 0.118 & 0.001 & $\%$ canopy cover \\
Flinders & 0.247 & 0.061 & 0.001 & $\%$ silt/clay, \% sand, \% detritus \\
Brisbane & 0.371 & 0.138 & 0.001 & $\%$ sand, \% cobble, \% bare, \% detritus \\
Moonie & 0.602 & 0.362 & 0.001 & $\%$ sticks, \% branches, \% logs \\
Tagliamento & 0.390 & 0.152 & 0.001 & $\%$ bare, \% vegetation \\
\hline
\end{tabular}

\section{Figures}

4 Fig. 1 Study sites in a) the Mitchell, Flinders, Brisbane and Moonie River catchments in the state of Queensland, Australia, and b) the Tagliamento River catchment, Italy

6 Fig. 2 Hydrographs of sites in each catchment for 1/01/2007-1/01/2010, displayed as discharge $\left(\mathrm{m}^{3} / \mathrm{s}\right)$ 7 for: a) the Flinders River, b) the Moonie River, c) the Walsh River in the Mitchell River catchment, and

8 d) Purga Creek in the Brisbane River catchment; and as stage (cm) for e) the Tagliamento River

9 (upstream of the section which dries completely). Arrows indicate the sampling date, except for the

10 Tagliamento River catchment as the hydrological data for this sampling period was unavailable

11 (September 2010). Note that the vertical axes have different scales. Seasons are shown, with $\mathrm{S}=$

12 summer, $\mathrm{A}=$ autumn, $\mathrm{W}=$ winter, $\mathrm{Sp}=$ spring

13 Fig. 3 Examples of dry river beds and substrate types in each catchment: a, b) Mitchell; c) Flinders; d)

14 Brisbane; e, f) Moonie; g, h) Tagliamento

15 Fig. 4 Terrestrial invertebrate assemblage composition (abundance data) from dry river bed (open 16 circles) and riparian (closed triangles) habitats for sites in: a) Mitchell River catchment; b) Flinders 17 River catchment; c) Brisbane River catchment; d) Moonie River catchment; e) Tagliamento River 18 catchment. Each point represents the mean $\mathrm{x}$ and $\mathrm{y}$ 2-Dimensional NMDS coordinate for each habitat at 19 each site $(a, b, c, d, e)$ with \pm 1 standard error as error bars. Stress is shown. See Table 1 for site codes

20 Fig. 5 Average proportional abundance (\%) of terrestrial invertebrate groups for dry river bed (B) and 21 riparian $(\mathrm{R})$ habitats in each catchment. Other $=$ terrestrial invertebrate groups that contributed $\leq 5 \%$ to 22 the invertebrate abundance for a catchment 


\section{colourrfigure \\ a) Mitchell}

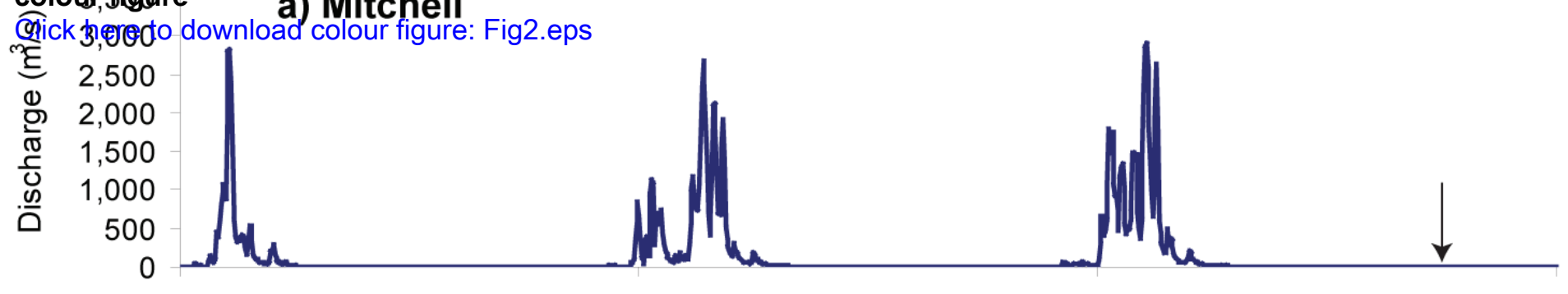

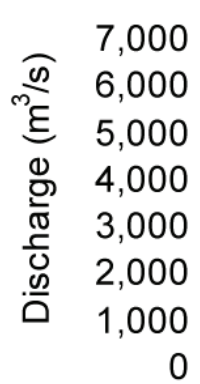

b) Flinders

b) Flinders

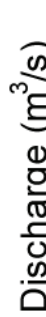

250 c) Brisbane

200

150

100

50

0
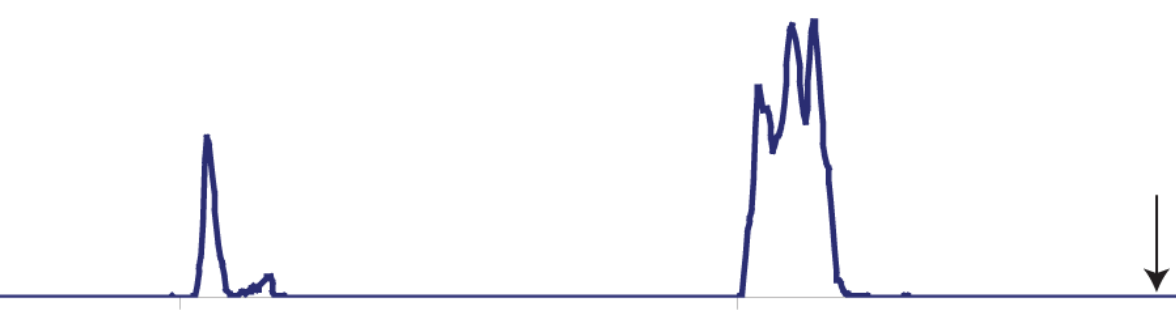

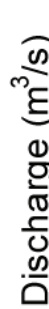

250
200
150
100
50
0

d) Moonie

A
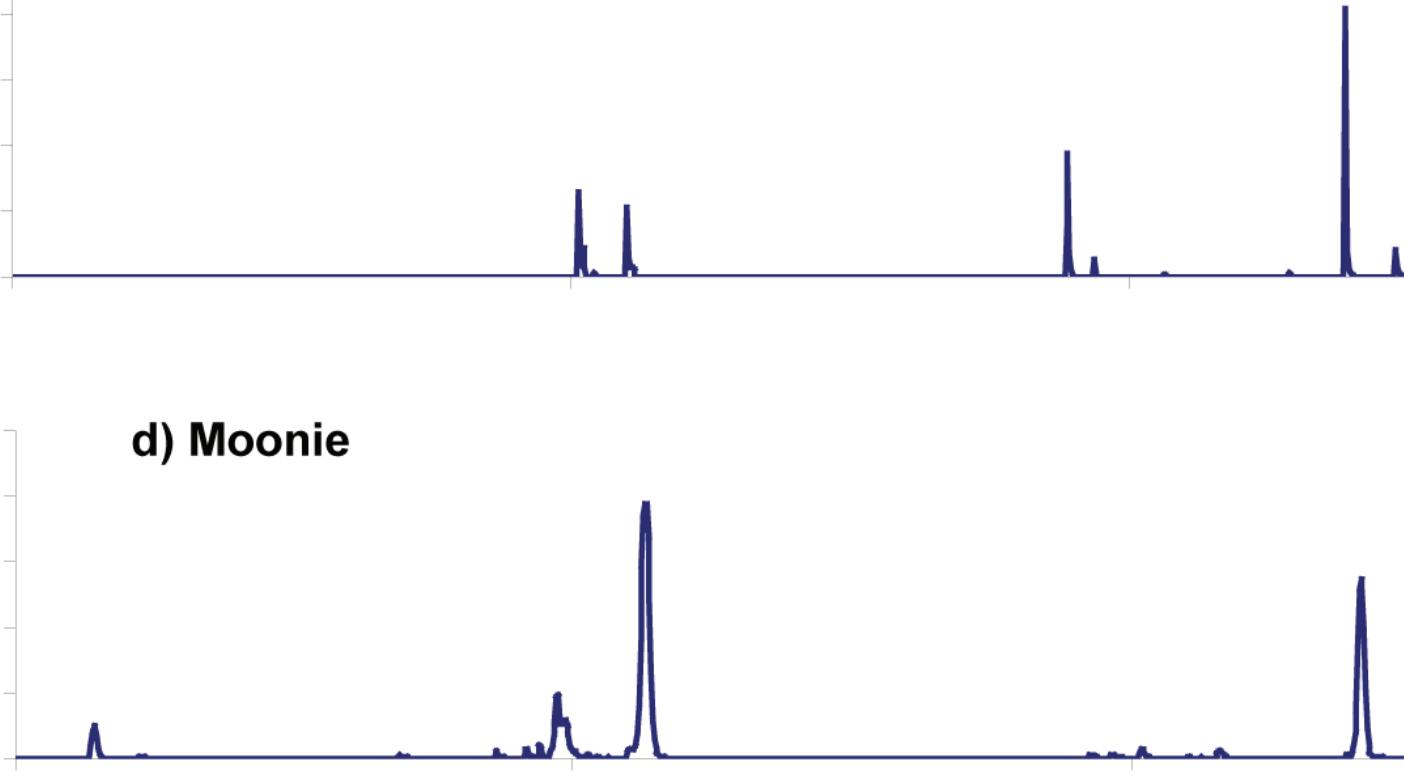

.

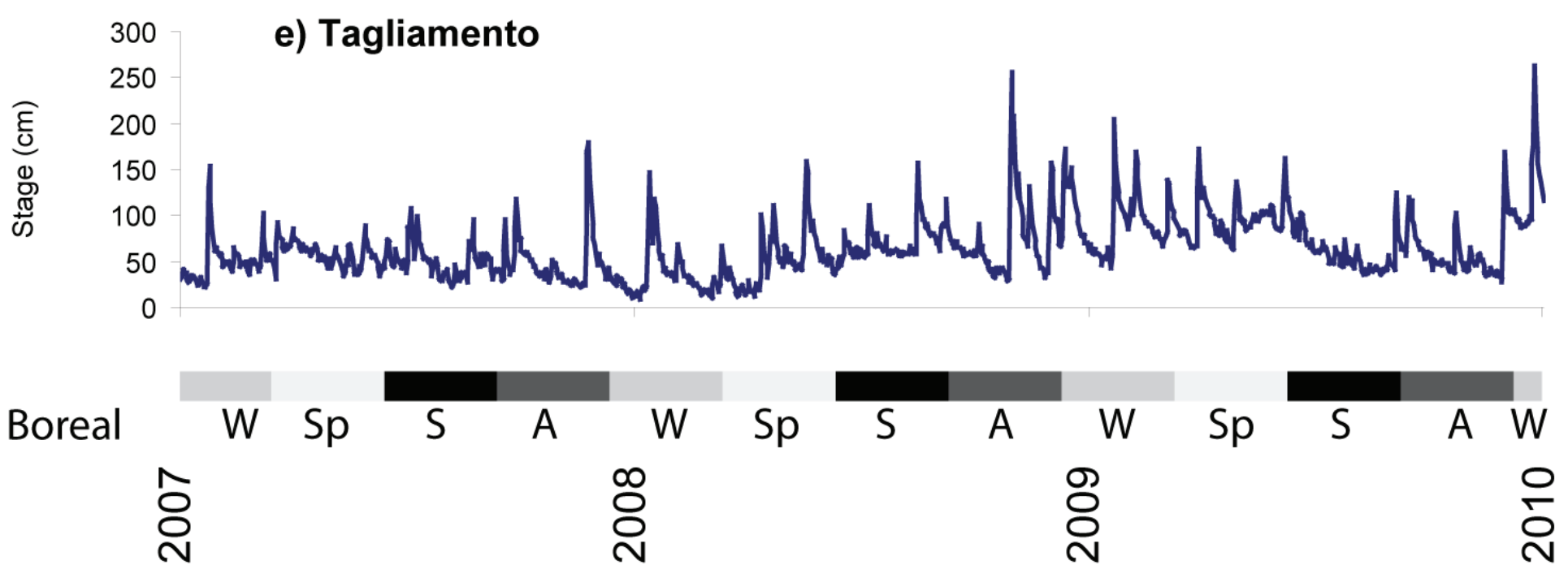




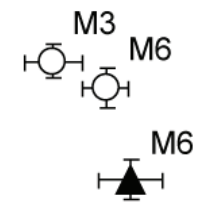<smiles>CS(=O)(=O)O</smiles>
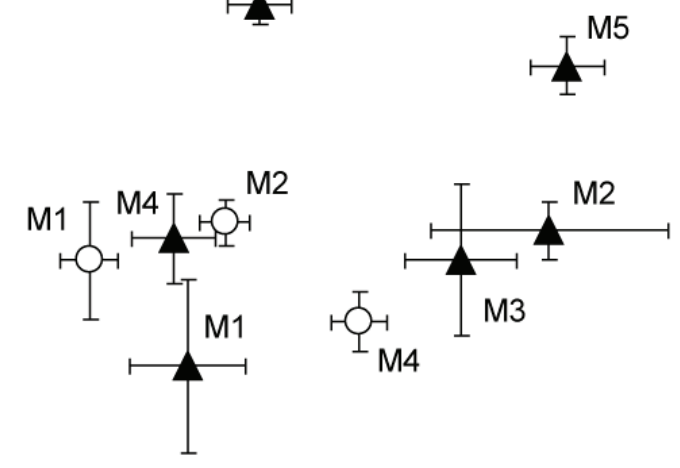
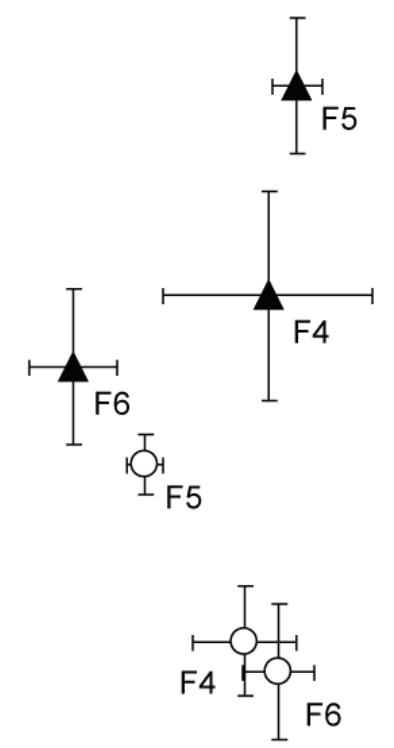

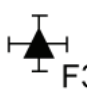

3

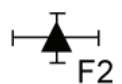

T

F1

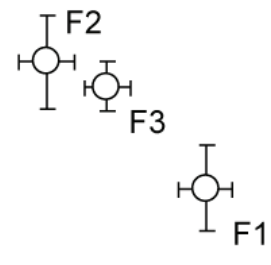

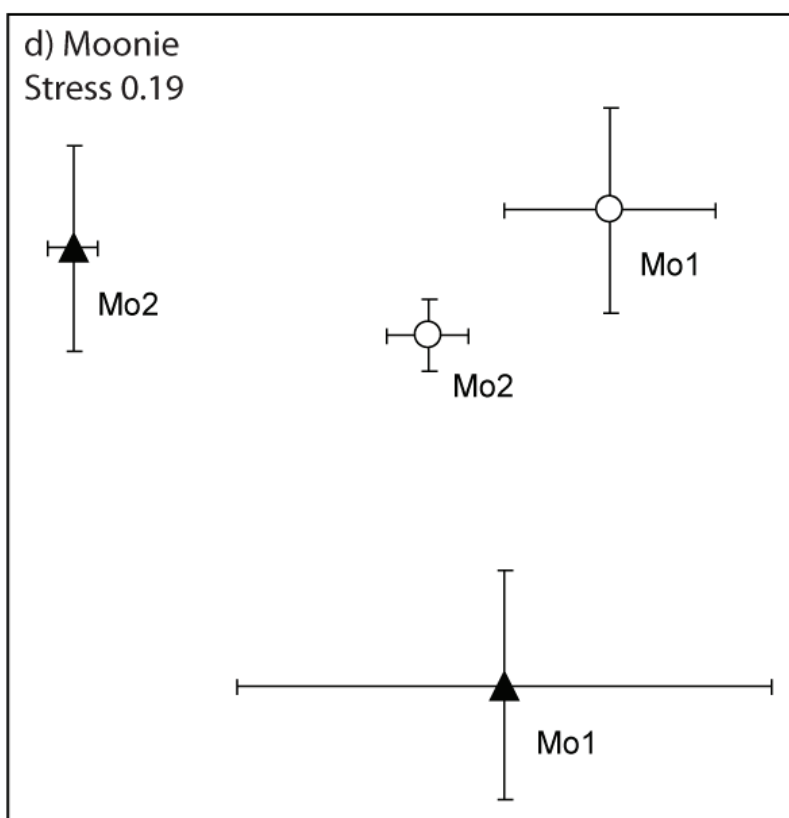

e) Tagliamento

Stress 0.23

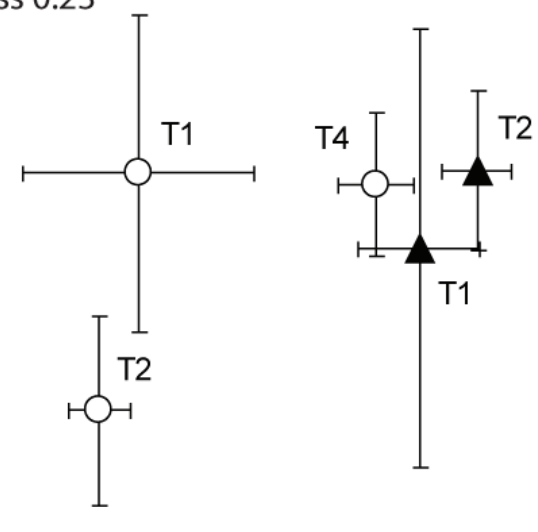

c) Brisbane

Stress 0.22

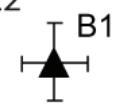

$\underbrace{\mathrm{B} 3}$
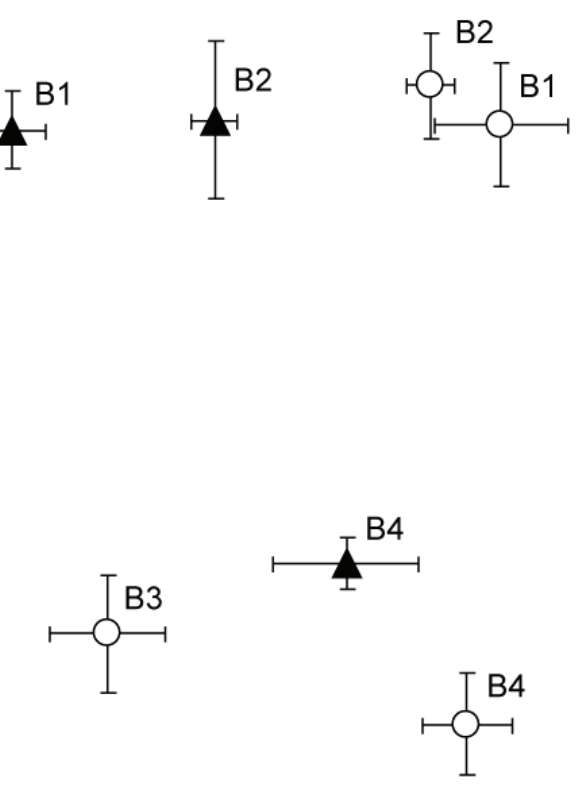

\section{ento}

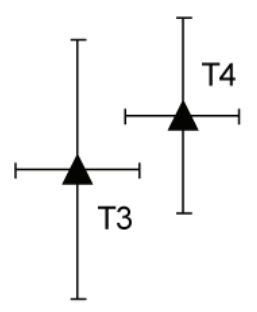

$\mathrm{I}^{\mathrm{T} 3}$ 
